\title{
Parameter Genetik Hasil Persilangan Jagung Bersari Bebas untuk Mendapatkan Galur Berbiji Ungu
}

\section{(Genetic Parameter Corn from Open Pollinated Hybridization Get Purple Lines Seed)}

\author{
Hanif Kusuma Abadi, Eries Dyah Mustikarini, Gigih Ibnu Prayoga
}

(Diterima September 2020/Disetujui Juli 2021)

\begin{abstract}
ABSTRAK
Jagung (Zea mays) merupakan tanaman serealia dan menjadi makanan pokok sebagian masyarakat. Jagung ungu memiliki kelebihan dibanding jagung pada umumnya karena kandungan gizi dan kadar antosianin yang tinggi Penelitian ini bertujuan mengevaluasi parameter genetik seperti variabilitas, heritabilitas, dan kemajuan genetik generasi $F_{2}$ hasil persilangan jagung bersari bebas. Penelitian dilaksanakan pada bulan Januari 2020 sampai Juni 2020 di Kebun Penelitian dan Percobaan Jurusan Agroteknologi Universitas Bangka Belitung. Penelitian menggunakan rancangan tanpa ulangan (single plant). Galur yang digunakan berasal dari hasil seleksi pada tahap seleksi sebelumnya, yaitu $F_{1}$. Hasil penelitian menunjukkan nilai variabilitas fenotip agak luas pada karakter bobot tongkol dengan kelobot dan bobot tongkol tanpa kelobot. Nilai heritabilitas tinggi terdapat pada karakter umur panen, umur berbunga jantan, dan umur berbunga betina. Nilai kemajuan genetik harapan tinggi terdapat pada karakter tinggi tanaman, jumlah baris biji, bobot $100 \mathrm{biji}$, dan bobot tongkol dengan kelobot. Dari hasil seleksi diperoleh sembilan galur jagung yang disarankan untuk seleksi generasi selanjutnya.
\end{abstract}

Kata kunci: biji ungu, heritabilitas, jagung, kemajuan genetik harapan, variabilitas

\section{ABSTRACT}

Corn (Zea mays) is a cereal crop and has become a staple food. Purple corn has more excess compared to corn in general. In addition, purple corn has high nutrient content and anthocyanin levels. This study aims to determine genetic parameters such as variability, heritability, and genetic advance of the F2 generation resulting from an openpollinated hybridization. The research was conducted from January 2020 to June 2020 on the Research and Experimental Field of the Department of Agrotechnology, Universitas Bangka Belitung. The work used a single plant design. The lines used were derived from the results of the previous selection stage. The results showed that the phenotype variability was relatively wide on the weight character of ear cobs with cornhusk, and the cob weight without cornhusk. High heritability values are found in the characters of harvest age, age of male flowering, and age of female flowering. The value of expected genetic advance for high expectations is found in the characters of plant height, the row number of seeds, the weight of 100 -seeds, and the weight of cob with cornhusk. The selection results suggest nine corn lines that can be used for the next generation selection.

Keywords: corn, expected genetic advance, heritability, purple, variability

\section{PENDAHULUAN}

Jagung merupakan salah satu jenis tanaman pangan yang diminati masyarakat Indonesia. Jagung dimanfaatkan sebagai bahan industri (Suhendrata 2012). Pemulia tanaman berperan dalam penyediaan varietas jagung unggul, khususnya jagung ungu dengan kandungan antosianin. Efektivitas seleksi tanaman jagung dapat diduga berdasarkan parameter genetik. Menurut Lubis (2014), karakter dikendalikan oleh faktor genetik yang ditunjukkan oleh nilai heritabilitas arti luas yang tinggi $(>70 \%)$. Dikenal tiga metode perakitan varietas dalam program pemuliaan

Jurusan Agroteknologi, Universitas Bangka Belitung, Balunjuk, Merawang, Bangka, Bangka Belitung 33172

* Penulis Korespondensi:

Email: eriesdyah79@gmail.com tanaman, yaitu seleksi, hibridisasi, dan hibridisasi yang dilanjutkan dengan seleksi (Amzeri 2015). Peneliti memanfaatkan sumber genetik yang tersedia untuk membentuk suatu varietas tanaman jagung yang diinginkan, misalnya dengan menggabungkan dua sifat yang berbeda, yaitu produksi tinggi dengan karakter khusus, seperti jagung ungu yang kaya akan kandungan antosianin (Bello et al. 2010).

Karakter yang diinginkan diseleksi secara bertahap pada setiap tahap pembentukan galur (Nzuve et al. 2014). Menurut Amzeri (2019) seleksi satu tongkolsatu baris merupakan salah satu metode seleksi pada tanaman yang menyerbuk silang untuk meningkatkan karakter kuantitatif suatu populasi. Parameter genetik tanaman jagung generasi $F_{2}$ perlu diduga agar proses seleksi dalam perakitan tanaman dapat berjalan dengan efektif. Parameter yang digunakan adalah nilai variabilitas, heritabilitas, dan kemajuan genetik 
harapan pada tanaman jagung. Informasi variabilitas genetik dan terdapatnya interaksi antara genetik dan lingkungan menjadi pertimbangan metode seleksi yang tepat untuk memperoleh karakter tanaman yang diinginkan (Sa'diyah et al. 2013). Variabilitas genetik menjadi salah satu kunci utama dalam program perakitan varietas tanaman jagung dengan karakter tertentu (Ahmad et al. 2011). Menurut Khomeani (2015), variabilitas yang bernilai rendah akan menyulitkan seleksi karena tingkat keseragaman yang tinggi. Nilai variabilitas tinggi lebih mudah diseleksi karena tingkat keseragaman yang rendah sehingga pemulia berpeluang yang lebih besar dalam menyeleksi karena memiliki karakter tanaman jagung yang lebih beragam.

Nilai duga heritabilitas penting diketahui dalam upaya mengetahui pewarisan dan metode seleksi yang tepat (Bello 2012). Menurut Kusuma et al. (2016), karakter tanaman yang penampilannya lebih dipengaruhi oleh faktor genetik daripada faktor lingkungan memiliki nilai heritabilitas tinggi dan berperan dalam mengendalikan pembentukan karakter. Heritabilitas menentukan kemajuan genetik, makin besar nilai heritabilitas makin besar pula kemajuan genetik, dan sebaliknya. Karakter seleksi harus memiliki keragaman dan heritabilitas yang tinggi, agar diperoleh target kemajuan genetik (Lubis et al. 2014). Menurut Barmawi et al. (2013), keragaman genetik dan heritabilitas bermanfaat untuk menduga kemajuan genetik dari seleksi. Tujuan penelitian ini adalah mengevaluasi nilai variabilitas, heritabilitas, dan kemajuan genetik harapan jagung ungu generasi $F_{2}$.

\section{METODE PENELITIAN}

\section{Waktu dan Tempat}

Kegiatan penelitian dilaksanakan di Kebun Penelitian dan Percobaan (KP2) Fakultas Pertanian, Perikanan dan Biologi, Universitas Bangka Belitung pada bulan Januari 2020-Juni 2020.

\section{Alat dan Bahan}

Alat analitis yang digunakan ialah Royal Horticultural Society Color Chart (RHS). Bahan yang digunakan adalah benih hasil seleksi pada generasi $F_{2}$ $\left(\mathrm{S}_{1}\right)$, pupuk kotoran sapi, NPK, fungisida, dan insektisida.

\section{Metode Penelitian}

Eksperimen menggunakan rancangan tanpa ulangan single plant. Tongkol-ke-baris (ear-to-row) digunakan sebagai metode seleksi. Bahan tanam yang digunakan sebanyak dua galur, diperoleh dari hasil seleksi pada generasi $F_{2}\left(S_{1}\right)$, dengan intensitas $10 \%$, yaitu $S_{1}-P x U-6$ dan $S_{1}-P x U-11$, jagung ungu lokal Marassempulu asal Sulawesi Selatan dan jagung putih lokal Magetan asal Jawa Timur yang digunakan sebagai varietas pembanding.
Penelitian ini menggunakan isolasi waktu dalam kurun dua pekan. Penanaman dilakukan secara berurutan mulai dari galur $\mathrm{S}_{1}-\mathrm{PxU}-6$, galur $\mathrm{S}_{1}-\mathrm{PxU}-11$, jagung ungu lokal Marassempulu, dan jagung putih lokal Magetan. Jumlah petak sebanyak empat petak. Setiap petak ditanami 30 tanaman yang sama dari galur atau tetua. Perbedaan waktu adalah untuk mencegah terjadinya segregasi antargalur atau tetua. Total sampel tanaman adalah 120 tanaman.

\section{Cara Kerja \\ - Pengolahan lahan}

Pengolahan lahan dimulai dengan membersihkan lahan menggunakan cangkul dari gulma dan akar tanaman pertanaman sebelumnya lalu beri patok menggunakan tali untuk dibuat petakan agar sesuai dengan ukuran. Ukuran petak ialah $3,5 \mathrm{~m} \times 1,5 \mathrm{~m}$ dengan jarak antarpetak, yaitu $1 \mathrm{~m}$. Pupuk organik diberikan sebanyak 10 ton/ha atau setara dengan 2,1 $\mathrm{kg} /$ petak.

\section{- Persiapan benih}

Benih diperoleh dari hasil seleksi sebelumnya, yaitu pada generasi $F_{2}\left(S_{1}\right)$. Benih dipilah dengan cara merendam benih menggunakan fungisida selama 1015 menit untuk memisahkan benih berisi dan hampa serta melindungi benih dari serangan fungi atau jamur. Benih yang tenggelam djadikan bahan tanam dalam kegiatan penelitian karena benih tersebut merupakan benih yang bernas/berisi. Diprioritaskan benih yang berwarna ungu untuk ditanam.

\section{- Penanaman}

Dibuat empat petak. Isolasi waktu diatur dengan selang waktu, yaitu 2 pekan antarpetak sehingga penanaman tidak serempak. Jarak tanam adalah 75 $\mathrm{cm} \times 20 \mathrm{~cm}$ (Litbang 2016). Setiap lubang tanam diberi 1 benih dengan kedalaman 2-3 cm. Jagung juga ditanam di luar bedeng untuk keperluan penyulaman. Pupuk NPK diaplikasikan dengan dosis $1 / 3$, yaitu 2,25 $\mathrm{g} /$ tanaman atau setara dengan $450 \mathrm{~kg} / \mathrm{ha}$.

\section{- Pemeliharaan}

Pemeliharaan meliputi penyiraman, pemupukan, pengendalian hama, penyakit, dan gulma. Tanaman disiram dengan volume yang sama, 1 kali sehari pada sore hari. Pemupukan lanjutan ialah dengan NPK pada 30 HST dengan dosis 2/3, yaitu 4,5 g/tanaman atau setara dengan $450 \mathrm{~kg} / \mathrm{ha}$. Hama dan penyakit dikendalikan dengan menggunakan pestisida yang disesuaikan dengan intensitas serangan dan dosis yang tertera pada label. Gulma dikendalikan dengan cara mencabuti gulma secara intensif.

\section{- Pemanenan}

Jagung dipanen pada sekitar 95-100 HST. Jagung yang siap panen atau disebut masak fisiologis ditandai dengan daun jagung/klobot telah kering, berwarna kekuning-kuningan, dan ada tanda hitam di bagian 
pangkal tempat melekatnya biji pada tongkol (Litbang 2016).

\section{Karakter yang Diamati}

\section{- variabel pengamatan Kuantitatif}

Tinggi tanaman diukur dari pangkal batang hingga daun tertinggi tanaman. Tinggi tanaman diukur pada fase after flowering. Umur tanaman berbunga dihitung berdasarkan jumlah hari sejak tanaman ditanam sampai tanaman berbunga pertama kali. Umur berbunga betina diamati pada saat keluarnya silk dari tongkol. Umur berbunga jantan diamati ketika munculnya tasel pada ujung batang.

Bobot 100-butir diperoleh dengan mengambil dan menimbang 100-butir biji kering dari setiap tongkol. Diameter tanaman diukur pada umur 78 HST, diukur pada bagian batang $5 \mathrm{~cm}$ dari permukaan tanah, dengan menggunakan jangka sorong. Bobot tongkol dengan kelobotnya ditimbang pascapanen. Umur panen dihitung berdasarkan jumlah hari sejak tanaman ditanam sampai tanaman siap panen. Jumlah daun dihitung berdasarkan semua daun yang muncul, ditetapkan pada fase after flowering.

Panjang dari pangkal tongkol sampai ujung tongkol jagung diukur dengan menggunakan mistar, setelah tongkol dipanen. Bobot tongkol dihitung tanpa kelobot dengan menimbang tongkol yang telah dibersihkan dari rambut dan kelobotnya. Jumlah baris biji dihitung berdasarkan semua biji yang muncul. Jumlah baris biji dihitung setelah panen.

\section{- Variabel pengamatan kualitatif}

Bentuk permukaan biji teratas ditentukan dengan cara mengamati secara visual dan disesuaikan dengan kriteria, yaitu (1) berkerut, (2) bergerigi, (3) datar, (4) bundar, (5) meruncing, atau (6) sangat meruncing. Bentuk daun diamati berdasarkan semua daun yang muncul pada saat fase after flowering. Jumlah daun diamati berdasarkan bentuk morfologi daun dan bentuk malai diamati ketika tanaman telah memasuki fase generatif pada fase after flowering. Pengamatan dilakukan pada morfologi malai dan baris biji berdasarkan semua biji yang telah muncul. Bentuk susunan baris biji ditentukan dengan cara mengamati secara visual dan disesuaikan dengan kriteria, yaitu (1) teratur, (2) tidak teratur, (3) lurus, atau (4) melengkung.

\section{Analisis Data}

Data kualitatif pengamatan dianalisis secara deskriptif. Karakter kuantitatif dianalisis dengan menggunakan rumus berikut.

\section{Perhitungan Variabilitas}

Nilai varians genetik, varians lingkungan, dan varians fenotip menjadi komponen penting dalam memperoleh nilai variabilitas. Nilai diperoleh dengan menggunakan rumus menurut Suharsono et al. (2006), yaitu

$$
\text { Ragam genotif }\left(\sigma_{g}^{2}\right): \sigma_{f}^{2}-\sigma_{e}^{2}
$$

$$
\begin{gathered}
\text { Ragam fenotip }\left(\sigma_{f}^{2}\right) \quad: \frac{\sum_{i}^{N}=1(x i-\mu)^{2}}{n} \\
\text { Ragam lingkungan }\left(\sigma^{2}{ }_{e}\right): \frac{: \sigma_{P 1}^{2}+\sigma_{P 2}^{2}+\cdots \ldots+\sigma_{P n}^{2}}{n}
\end{gathered}
$$

Langkah berikutnya ialah menentukan koefisien keragaman fenotip (KKF) dan koefisien keragaman genetik (KKG):

$$
\begin{aligned}
& \% \mathrm{KKF}=\frac{\sqrt{\sigma_{f}^{2}}}{\text { Rataan Populasi }} \times 100 \\
& \% \mathrm{KKG}=\frac{\sqrt{\sigma_{g}^{2}}}{\text { Rataan Populasi }} \times 100
\end{aligned}
$$

Keterangan:

$\sigma^{2}{ }_{P 1} \quad=$ Ragam tetua betina

$\sigma^{2} P 2 \quad=$ Ragam tetua jantan

$\sigma_{g}^{2} \quad=$ Varians genotip

$\sigma_{f}^{2} \quad=$ Varians fenotip

$\sigma^{2} e_{e} \quad=$ Varians galat

$X_{i}{ }^{e}=$ Nilai pengamatan tanaman ke-1

$\mu \quad=$ Nilai tengah populasi

$\mathrm{n}=$ Jumlah tanaman

Menurut Moedjiono dan Mejaya (1994), kriteria KKF dan KKG dibagi menjadi empat, yaitu 0-25\% (sempit), 25-50\% (agak sempit), $50-70 \%$ (agak luas), dan 75-100\% (luas).

\section{Perhitungan Heritabilitas}

Nilai dugaan heritabilitas $h^{2}(B S)$ dalam arti luas berdasarkan analisis varians menurut Syukur et al. (2012) adalah

$$
\mathrm{h}^{2}(\mathrm{BS})=\frac{\sigma_{F 2}^{2}-\sqrt{\left(\sigma^{2} P 1\right)\left(\sigma^{2} P 2\right)}}{\sigma^{2} F 2} \times 100 \%
$$

Keterangan:

$\mathrm{h}^{2}(\mathrm{BS})=$ Heritabilitas

$\sigma_{F 2}^{2}=$ Ragam $F_{2}$

$\sigma^{2}{ }_{P 1}=$ Ragam tetua betina

$\sigma_{P 2}^{2}=$ Ragam tetua jantan

Kriteria nilai heritabilitas adalah sebagai berikut (Mendez-Natera et al. 2012), yaitu rendah $(\mathrm{H}<20 \%)$, sedang $(20 \% \leq H \geq 50 \%)$ dan tinggi $(H>50 \%)$.

\section{Perhitungan Kemajuan Genetik Harapan}

Menurut Mangoendidjojo (2003), nilai kemajuan genetik harapan $(\mathrm{KGH})$ dapat dihitung dengan menggunakan rumus:

$$
\begin{gathered}
\mathrm{KGH}=\mathrm{i} . \mathrm{h}^{2} . \sigma p \\
\% \mathrm{KGH}=\frac{\mathrm{KGH}}{\mu} \times 100 \%
\end{gathered}
$$

Keterangan:

$\mathrm{KGH}=$ Kemajuan genetik harapan

I = Intensitas seleksi $(10 \%=1,76)$

$\mathrm{h}_{2}(\mathrm{BS})=$ Heritabilitas 
op = Standar deviasi fenotip

$\mu \quad=$ Nilai rata-rata

Kriteria kemajuan genetik ialah sebagai berikut: rendah $(0<\mathrm{KGH} \leq 3,3 \%)$, agak rendah $(3,3 \%<\mathrm{KGH}$ $\leq 6,6 \%)$, cukup tinggi $(6,6 \%<\mathrm{KGH} \leq 10 \%)$, dan tinggi (KGH > 10\%).

\section{HASIL DAN PEMBAHASAN}

Penelitian dilakukan pada empat genotipe, yaitu dua tanaman jagung tetua (tetua putih dan tetua ungu), serta dua galur $\mathrm{F}_{2}$ tanaman jagung (galur $\mathrm{F}_{2}-\mathrm{PxU}-6$ dan $\mathrm{F}_{2}-\mathrm{PxU}-11$ ). Seleksi diterapkan dengan intensitas 25\%. Karakter kuantitatif dan kualitatif digunakan untuk proses seleksi tanaman jagung. Analisis dilakukan terhadap variabilitas fenotipik dan variabilitas genotipik (Tabel 1). Nilai diperoleh dari hasil pengamatan karakter pada tanaman. Var g dan var $\mathrm{f}$ kriteria sempit terdapat pada karakter umur panen, tinggi tanaman, jumlah daun, panjang tongkol, umur berbunga jantan, dan umur berbunga betina. Kriteria var $g$ dan $f$ agak sempit terdapat pada jumlah baris biji. Karakter dengan kriteria var $\mathrm{f}$ agak sempit dan var $\mathrm{g}$ sempit dijumpai pada karakter diameter batang dan bobot 100-biji. Kriteria var $\mathrm{f}$ agak luas dan var $\mathrm{g}$ sempit ada pada bobot tongkol dengan kelobot dan bobot tongkol tanpa kelobot.

Nilai heritabilitas pada sebelas karakter kuantitatif yang diamati dibagi menjadi beberapa kriteria, yaitu rendah, sedang, dan tinggi. Dari hasil perhitungan diperoleh kriteria heritabilitas rendah terdapat pada tiga karakter, yaitu panjang tongkol, bobot tongkol dengan kelobot, dan bobot tongkol tanpa kelobot. Kriteria heritabilitas yang tinggi dapat menjadi indikasi bahwa gen dari tetua diturunkan dengan kuat ke generasi selanjutnya. Kriteria heritabilitas tinggi terdapat pada dua karakter yang berhubungan dengan umur, yaitu umur panen, umur berbunga jantan dan umur berbunga betina (Tabel 2). Karakter dengan kriteria heritabilitas tinggi dapat menjadi acuan seleksi untuk generasi selanjutnya sesuai dengan tujuan pemulia.

Karakter yang berkaitan dengan tongkol seperti jumlah baris biji, bobot 100-biji, dan bobot tongkol dengan kelobot memiliki kriteria KGH tinggi, di samping tinggi tanaman. Karakter kuantitatif selanjutnya diseleksi pada galur sesuai dengan tujuan yang

Tabel 1 Nilai rata-rata, varians fenotip, varians genotip, koefisien keragaman genotip, dan koefisien keragaman fenotip karakter jagung ungu generasi $F_{2}$ hasil persilangan bersari bebas

\begin{tabular}{lrrrrrrr}
\hline Karakter & \multicolumn{1}{c}{$\mathrm{x}$} & \multicolumn{1}{c}{$\sigma^{2}{ }_{f}$} & \multicolumn{1}{c}{$\sigma_{g}{ }$} & KKF $(\%)$ & $\begin{array}{c}\text { Kriteria } \\
\text { Var } f\end{array}$ & $\begin{array}{c}\text { KKG } \\
(\%)\end{array}$ & $\begin{array}{c}\text { Kriteria } \\
\text { Var g }\end{array}$ \\
\hline UP & 80,24 & 5,16 & 3,59 & 2,83 & Sempit & 2,36 & Sempit \\
TT & 161,49 & 1213,11 & 562,35 & 21,57 & Sempit & 14,68 & Sempit \\
JBB & 14,30 & 50,86 & 28,09 & 49,86 & Agak sempit & 37,06 & Agak sempit \\
JD & 8,05 & 1,40 & 0,34 & 14,66 & Sempit & 7,33 & Sempit \\
DB & 11,75 & 9,08 & 0,78 & 25,62 & Agak sempit & 7,57 & Sempit \\
PT & 11,59 & 7,61 & 1,13 & 23,81 & Sempit & 6,38 & Sempit \\
B100 & 26,32 & 49,82 & 38,19 & 26,82 & Agak sempit & 23,48 & Sempit \\
BTDK & 72,84 & 1363,38 & $-84,32^{*}$ & 50,69 & Agak luas & 18,99 & Sempit \\
BTTK & 54,27 & 911,06 & 78,91 & 55,61 & Agak luas & 5,69 & Sempit \\
UJ & 41,59 & 7,86 & 6,33 & 6,73 & Sempit & 6,06 & Sempit \\
UB & 45,62 & 5,86 & 3,06 & 5,30 & Sempit & 3,84 & Sempit \\
\hline
\end{tabular}

Keterangan: $\mathrm{x}$ (rata-rata), $\sigma_{f}^{2}$ (ragam fenotip), $\sigma_{g}^{2}$ (ragam genotip), KKF (koefisien keragaman fenotip), KKG (koefisien keragaman genetik), Var F (variabilitas fenotipik), Var G (variabilitas genotipik), UP (umur panen), TT (tinggi tanaman), JBB (jumlah baris biji), JD (jumlah daun), DB (diameter batang), PT (panjang tongkol), B100 (bobot $100 \mathrm{biji}$ ), BTDK (bobot tongkol dengan kelobot), BTTK (bobot tongkol tanpa kelobot), UJ (umur berbunga jantan), UB (umur berbunga betina). Kriteria variabilitas adalah 0-25\% (Sempit), 25-50\% (Agak sempit), 50-70\% (Agak luas), dan 75-100\% (Luas) (Moedjiono dan Mejaya 1994). * = dianggap nol (0) (Maryenti 2014).

Tabel 2 Nilai heritabilitas jagung ungu generasi $F_{2}$

\begin{tabular}{lcl}
\hline \multicolumn{1}{c}{ Karakter } & Heritabilitas (\%) & Kriteria \\
\hline Umur panen (HST) & 73,45 & Tinggi \\
Tinggi tanaman (cm) & 42,62 & Sedang \\
Jumlah baris biji (baris) & 46,22 & Sedang \\
Jumlah daun (helai) & 25,00 & Sedang \\
Diameter batang (mm) & 20,15 & Sedang \\
Panjang tongkol (cm) & $-6,70^{\star}$ & Rendah \\
Bobot 100 biji (gram) & 48,74 & Sedang \\
Bobot tongkol dengan kelobot (gram) & $-11,95^{\star}$ & Rendah \\
Bobot tongkol tanpa kelobot (gram) & $-0,81^{*}$ & Rendah \\
Umur berbunga jantan (HST) & 78,37 & Tinggi \\
Umur berbunga betina (HST) & 63,48 & Tinggi \\
\hline
\end{tabular}

Keterangan: Rentang nilai heritabilitas <20\% (rendah), 20\%-50\% (sedang) dan $>50 \%$ untuk kategori tinggi (Mendez-Natera et al. 2012). ${ }^{*}=$ dianggap nol (0) (Maryenti 2014). 
diinginkan oleh penelit, yakni karakter yang memiliki kriteria KGH tinggi. Karakter yang dapat digunakan untuk kegiatan seleksi generasi selanjutnya adalah tinggi tanaman, jumlah baris biji, bobot 100-biji, dan bobot tongkol dengan kelobot (Tabel 3).

Sembilan galur terbaik terpilih berdasarkan karakter kuantitatif dan kualitatif. Karakter utama yang terpilih adalah warna biji dan hasil. Karakter umur panen tercepat, yaitu 78 hari, terdapat pada empat galur. Karakter tinggi tanaman dengan hasil terbaik terdapat pada galur $\mathrm{F}_{2}-\mathrm{PxU}-11-2$, yaitu $186 \mathrm{~cm}$ (Tabel 4). Karakter jumlah baris biji memperlihatkan hasil yang beragam. Galur tersebut juga terbaik dengan jumlah baris biji terbanyak, yaitu 23 baris, selain memiliki jumlah daun terbanyak, yaitu 10 helai daun per tanaman. Karakter diameter batang diperoleh oleh galur terbaik tersebut, dengan diameter batang 12,73 $\mathrm{mm}$ di samping panjang tongkol, yaitu $12 \mathrm{~cm}$, serta terbaik dengan bobot 100-biji sebesar 16,2 gram. Hasil terbaik karakter bobot tongkol dengan kelobot dan tanpa kelobot juga ditampilkan oleh galur tersebut, masing-masing dengan bobot $93 \mathrm{~g}$ dan $68 \mathrm{~g}$. Demikian pula, karakter umur berbunga betina terbaik, yaitu 44 hari. Karakter umur berbunga jantan tercepat terdapat pada galur $\mathrm{F}_{2}-\mathrm{PxU}-6-17$ dan $\mathrm{F}_{2}-\mathrm{PxU}-11-5$, yaitu 39 hari. (Tabel 4).

Pemeringkatan dilakukan dengan memilih galur yang memiliki warna biji menyerupai warna tetua ungu, yaitu kelompok dark red. Warna biji menjadi karakter utama dalam kegiatan seleksi ini (Tabel 4). Semua galur yang diuji memiliki warna yang sama atau menyerupai warna tetua ungu (dark red).

Secara umum, galur $\mathrm{F}_{2}-\mathrm{PxU}-11$ dan $\mathrm{F}_{2}-\mathrm{PxU}-6$, berbentuk daun sama dengan kriteria bentuk daun 1 (pointed). Hasil berbeda terletak pada karakter bentuk malai, secara umum galur $\mathrm{F}_{2}-\mathrm{PxU}-11$ dan $\mathrm{F}_{2}$-PxU-6 memiliki skor mayoritas, yaitu skor 1 (very slightly recurved). Skor 3 (slightly recurverd), hanya terdapat pada dua galur, yaitu galur $\mathrm{F}_{2}-\mathrm{PxU}-11-5$ dan $\mathrm{F}_{2}-\mathrm{PxU}-6-$ 25 . Dari hasil pengamatan ditemukan warna daun yang sama pada mayotitas galur, yaitu warna greyish olivegreen A. Warna daun yang berbeda (greyish olivegreen $\mathrm{B}$ ), hanya terdapat pada satu galur, yaitu $\mathrm{F}_{2}$ PxU-6-25 (Tabel 5).

Dari hasil pengamatan karakter susunan baris biji diperoleh dua skor, yaitu skor 1 (teratur) dan skor 2 (tidak teratur), sedangkan karakter bentuk permukaan biji teratas terdapat tiga macam skor, yaitu 1 (berkerut), 3 (datar), dan 4 (bundar). Galur generasi $F_{2}$ yang memiliki susunan baris biji kriteria 1 (teratur) dan bentuk permukaan biji teratas kriteria 3 (datar) hanya terdapat pada satu galur, yaitu $\mathrm{F}_{2}-\mathrm{PxU}-11-2$. Galurgalur lain memiliki hasil yang cenderung beragam (Tabel 5).

Galur generasi F2 berasal dari persilangan jagung lokal putih Magetan dan lokal ungu Masempulur.

Tabel 3. Nilai kemajuan genetik harapan jagung ungu generasi $F_{2}$.

\begin{tabular}{lrrll}
\hline \multicolumn{1}{c}{ Karakter } & \multicolumn{1}{c}{$\mathrm{x}$} & \multicolumn{1}{c}{ KGH } & KGH $(\%)$ & Kriteria \\
\hline Umur panen & 80,24 & 2,93 & 3,66 & Agak rendah \\
Tinggi tanaman & 161,49 & 26,13 & 16,18 & Tinggi \\
Jumlah baris biji & 14,30 & 5,80 & 40,56 & Tinggi \\
Jumlah daun & 8,05 & 0,52 & 6,45 & Agak rendah \\
Diameter batang & 11,75 & 1,07 & 9,09 & Cukup tinggi \\
Panjang tongkol & 11,59 & 0,33 & 2,81 & Rendah \\
Bobot 100 biji & 26,32 & 6,06 & 23,01 & Tinggi \\
Bobot tongkol dengan kelobot & 72,84 & 7,77 & 10,67 & Tinggi \\
Bobot tongkol tanpa kelobot & 54,27 & 0,43 & 0,79 & Rendah \\
Umur berbunga jantan & 41,59 & 3,86 & 9,29 & Cukup tinggi \\
Umur berbunga betina & 45,62 & 2,70 & 5,93 & Agak rendah \\
\hline
\end{tabular}

Keterangan: $\mathrm{KGH}$ (Kemajuan Genetik Harapan); $0<\mathrm{KGH} \leq 3,3 \%$ (rendah), 3,3\% < KGH $\leq 6,6 \%$ (agak rendah), 6,6\% < $\mathrm{KGH} \leq 10 \%$ (cukup tinggi) dan $\mathrm{KGH}>10 \%$ (tinggi) (Mangoendidjojo 2003).

Tabel 4 Galur generasi $F_{2}$ terpilih berdasarkan intensitas seleksi 25\% berdasarkan karakter kuantitatif dan karakter kualitatif tanaman jagung hasil persilangan bersari bebas

\begin{tabular}{|c|c|c|c|c|c|c|c|c|c|c|c|c|c|}
\hline \multirow{2}{*}{ Galur } & & \multicolumn{12}{|c|}{ Karakter } \\
\hline & $R^{\prime}$ & UP & TT & JB & JD & DB & PT & $\mathrm{B} 100$ & BDK & BTK & UJ & UB & SWB \\
\hline$F_{2}-P x U-11-2$ & 1 & 79 & 186 & 23 & 10 & 12,73 & 12 & 16,2 & 93 & 68 & 40 & 44 & $D R(\mathrm{~B})$ \\
\hline$F_{2}-P x U-6-30$ & 2 & 78 & 166 & 12 & 8 & 11,33 & 6,4 & 14,0 & 86 & 59 & 45 & 47 & $D R(\mathrm{~B})$ \\
\hline$F_{2}-P x U-6-9$ & 3 & 78 & 179 & 14 & 8 & 10,61 & 10,5 & 15,3 & 16 & 10 & 46 & 50 & $D R(\mathrm{~B})$ \\
\hline$F_{2}-P x U-11-7$ & 4 & 79 & 130 & 13 & 7 & 9,6 & 11 & 14,4 & 90 & 68 & 41 & 45 & $D R(\mathrm{C})$ \\
\hline$F_{2}-P x U-6-29$ & 5 & 78 & 159 & 3 & 8 & 10,13 & 10,5 & 7,2 & 39 & 20 & 44 & 47 & $D R(\mathrm{~B})$ \\
\hline$F_{2}-P x U-6-17$ & 6 & 85 & 104 & 12 & 8 & 10,17 & 8,5 & 12,3 & 32 & 21 & 39 & 53 & $D R(\mathrm{~B})$ \\
\hline$F_{2}-P x U-6-25$ & 7 & 85 & 143 & 2 & 6 & 7,9 & 7 & 3,0 & 33 & 15 & 45 & 47 & $D R(\mathrm{~A})$ \\
\hline $\mathrm{F}_{2}-\mathrm{PxU}-6-6$ & 8 & 78 & 115 & 3 & 7 & 10,1 & 8 & 4,5 & 59 & 48 & 45 & 47 & $D R(\mathrm{~B})$ \\
\hline $\mathrm{F}_{2}-\mathrm{P} \times \mathrm{U}-11-5$ & 9 & 79 & 125 & 13 & 7 & 7,25 & 10 & 8,1 & 23 & 16 & 39 & 44 & $D R(\mathrm{~A})$ \\
\hline
\end{tabular}

Keterangan: R (ranking galur), UP (umur panen), TT (tinggi tanaman), JB (jumlah baris biji), JD (jumlah daun), DB (diameter batang), PT (panjang tongkol), B100 (bobot 100 biji), BDK (bobot tongkol dengan kelobot), BTK (bobot tongkol tanpa kelobot), UJ (umur berbunga jantan), UB (umur berbunga betina), SWB (sebaran warna biji), DR (dark red). 
Tabel 5 Karakter bentuk daun, warna daun dan bentuk malai galur generasi $F_{2}$

\begin{tabular}{|c|c|c|c|c|c|}
\hline Galur & Bentuk Malai & $\begin{array}{l}\text { Bentuk } \\
\text { Daun }\end{array}$ & Warna Daun & Susunan Baris Biji & $\begin{array}{c}\text { Bentuk Permukaan } \\
\text { Biji Teratas }\end{array}$ \\
\hline$F_{2}-P x U-11-2$ & pointed & $\begin{array}{c}\text { sangat } \\
\text { sedikit } \\
\text { melengku } \\
n g\end{array}$ & Hijau ke abu-buan (A) & berkerut & lurus \\
\hline$F_{2}-P x U-6-30$ & pointed & $\begin{array}{c}\text { sangat } \\
\text { sedikit } \\
\text { melengku } \\
\text { ng }\end{array}$ & Hijau ke abu-abuan (A) & bergerigi & melengkung \\
\hline $\mathrm{F}_{2}-\mathrm{PxU}-6-9$ & pointed & $\begin{array}{c}\text { sangat } \\
\text { sedikit } \\
\text { melengku } \\
n g\end{array}$ & Hijau ke abu-abuan (A) & berkerut & melengkung \\
\hline$F_{2}-P x U-11-7$ & pointed & $\begin{array}{c}\text { sangat } \\
\text { sedikit } \\
\text { melengku } \\
\text { ng }\end{array}$ & Hijau ke abu-abuan (A) & bergerigi & melengkung \\
\hline$F_{2}-P x U-6-29$ & pointed & $\begin{array}{c}\text { sangat } \\
\text { sedikit } \\
\text { melengku } \\
n g\end{array}$ & Hijau ke abu-abuan (A) & bergerigi & melengkung \\
\hline $\mathrm{F}_{2}-\mathrm{PxU}-6-17$ & pointed & $\begin{array}{c}\text { sangat } \\
\text { sedikit } \\
\text { melengku } \\
n g\end{array}$ & Hijau ke abu-abuan (A) & bergerigi & melengkung \\
\hline$F_{2}-P x U-6-25$ & rounded & $\begin{array}{c}\text { sangat } \\
\text { sedikit } \\
\text { melengku } \\
n g\end{array}$ & Hijau ke abu-abuan (B) & berkerut & teratur \\
\hline $\mathrm{F}_{2}-\mathrm{P} \times \mathrm{U}-6-6$ & pointed & $\begin{array}{c}\text { sangat } \\
\text { sedikit } \\
\text { melengku } \\
n g\end{array}$ & Hijau ke abu-abuan (A) & bergerigi & melengkung \\
\hline$F_{2}-P x U-11-5$ & rounded & $\begin{array}{c}\text { sangat } \\
\text { sedikit } \\
\text { melengku } \\
n g\end{array}$ & Hijau ke abu-abuan (A) & bergerigi & teratur \\
\hline
\end{tabular}

Keterangan: Kriteria karakter kualitatif tanaman jagung (CPVO 2010).

Seleksi generasi $F_{2}$ menunjukkan kriteria variabilitas luas dan heritabilitas yang rendah disebabkan oleh faktor genetik yang cenderung belum stabil. Galur generasi F2 menunjukkan kriteria variabilitas yang cenderung sempit dan heritabilitas cenderung sedang disebabkan terjadi penurunan populasi tanaman pada saat penelitian. Hal ini diduga karena masa panen seleksi generasi sebelumnya yang terlalu cepat, penyimpanan yang tidak tepat, proses pengeringan benih, serta faktor genetik seperti kualitas benih. Kualitas benih berkait erat dengan viabilitas dan vigor benih (Lesilolo et al. 2013). Menurut Tatipata (2014), indikasi dalam kemunduran benih dicirikan dengan menurunnya aktivitas enzim dan menurunnya cadangan makanan.

Nilai variabilitas dapat dilihat dari ragam genotip dan fenotip suatu karakter sehingga perlu diketahui informasi setiap karakter yang terdapat pada kegiatan seleksi. Menurut Ramadhani et al. (2013), informasi karakter setiap individu digunakan untuk mengevaluasi bentuk keragaman genotip. Keragaman genotip yang tinggi dapat meningkatkan peluang untuk memperoleh kultivar unggul dibandingkan dengan ragam genotip yang rendah. Hal ini sejalan dengan pendapat Jameela et.al (2014), semakin tinggi keragaman genetik, semakin besar peluang keberhasilan pemuliaan tanaman.

Keberhasilan kegiatan seleksi pada program pemuliaan tanaman erat kaitannya dengan keragaman genetik dan nilai duga heritabilitas. Keragaman adalah perbedaan sifat individu pada setiap populasi antara tanaman yang satu dengan tanaman yang lainnya (Apriliyanti dan Soetopo 2016). Hasil pengamatan menunjukkan nilai variabilitas fenotipik dan variabilitas genotipik yang cenderung sempit pada berbagai karakter seperti umur panen, jumlah daun, diameter batang, panjang tongkol, umur berbunga jantan, dan umur berbunga betina. Karakter bobot tongkol dengan kelobot memiliki variabilitas fenotipik agak luas namun variabilitas genotipik yang sempit. Hal ini mengindikasikan bahwa secara genotip, karakter ini lebih dipengaruhi oleh lingkungan dibandingkan dengan genetiknya.

Nilai variabilitas dengan kriteria sempit terdapat pada tiga karakter, seperti umur panen, umur berbunga jantan, dan umur berbunga betina. Pemanenan yang 
hampir serempak dapat menjadi indikasi sempitnya nilai variabilitas pada kriteria ini, hal ini diduga karena jumlah populasi yang berkurang drastis. Variabilitas yang sempit disebabkan oleh keragaman genetik yang sempit. Nilai keragaman genotif memiliki hasil yang tidak jauh berbeda dengan keragaman fenotip.

Nilai variabilitas beberapa karakter menunjukkan hasil dengan kriteria sempit seperti umur panen, tinggi tanaman, jumlah daun, diameter batang, panjang tongkol, bobot 100-biji, bobot tongkol dengan kelobot, bobot tongkol tanpa kelobot, umur berbunga jantan, dan umur berbunga betina. Menurut Aminasih (2010), nilai KKG dapat menjadi indikasi tinggi rendahnya keragaman genetik suatu karakter yang diseleksi. Menurut Effendy et al. (2018), keragaman genetik yang tinggi suatu karakter pada populasi dapat menjadi indikasi semakin beragamnya sifat pada karakter tersebut.

Heritabilitas diklasifikasikan berdasarkan kriteria rendah sedang hingga tinggi (Mendez-Natera et al. 2012). Karakter yang memiliki heritabilitas tinggi adalah karakter yang berhubungan dengan umur seperti umur panen $(73,45 \%)$, umur berbunga jantan $(78,37)$, serta umur berbunga betina $(63,48 \%)$ (Tabel 2). Karakter nilai heritabilitas rendah disebabkan oleh pengaruh lingkungan yang lebih tinggi daripada pengaruh genetik. Hal ini didukung oleh Sadras dan Slafer (2012), bahwa heritabilitas rendah dapat disebabkan oleh pengaruh lingkungan yang tinggi. Seleksi karakter dengan nilai heritabilitas tinggi akan lebih efektif dibandingkan dengan karakter yang memiliki heritabilitas yang rendah. Hal ini sejalan dengan pendapat Handayani dan Hidayat (2012), bahwa kegiatan seleksi dapat berjalan efektif jika menggunakan populasi dengan keragaman genetik yang luas serta heritabilitas tinggi.

$\mathrm{KGH}$ yang diperoleh dari hasil pengamatan terbagi menjadi beberapa kriteria. Karakter yang memiliki kriteria tinggi terdapat pada tinggi tanaman, jumlah baris biji, bobot 100-biji, dan bobot tongkol dengan kelobot. Dari penelitian ini ditemukan bahwa karakter tinggi tanaman dan karakter kelompok tongkol memiliki nilai KGH yang tinggi, maka karakter ini dapat menjadi bahan seleksi pada generasi selanjutnya, yaitu $F_{3}$. Hal ini sesuai dengan pernyataan Kristamtini et al. (2016), yakni karakter dengan nilai kemajuan genetik yang tinggi dapat mewariskan sifat dari tetua kepada anakan dengan lebih mudah sehingga dapat menjadi acuan seleksi pada kegiatan seleksi lanjutan.

Karakter dengan $\mathrm{KGH}$ tinggi ialah tinggi tanaman jumlah baris biji, bobot 100-biji, dan bobot tongkol dengan kelobot. Menurut Farnia dan Mansouri (2015), karakter tinggi tanaman, diameter batang, bobot dan panjang tongkol jagung dipengaruhi oleh populasi tanaman dan lingkungan. Lingkungan tanaman yang relatif sama akan memunculkan karakter kualitatif yang hampir sama pada setiap individu dalam suatu populasi. Hal ini dapat dilihat dari karakter bentuk daun dan warna daun jagung yang cenderung memiliki hasil yang hampir sama. Karakter ini memunculkan hasil yang hampir sama, yakani kriteria bentuk daun (pointed), dan warna daun (greyish olive-green A) (Tabel 4).

Galur $\mathrm{F}_{2}$-PxU-6-25 memiliki warna daun yang berbeda, yaitu greyish olive-green $\mathrm{B}$. Hal ini diduga karena galur tersebut memiliki nilai heritabilitas tinggi. Menurut Wirawan et al. (2013), nilai heritabilitas tinggi dapat menjadi indikasi bahwa faktor genetik tanaman lebih berpengaruh dibandingkan faktor lingkungan. Nilai heritabiltias tinggi juga terdapat pada karakter umur panen. Umur panen yang tinggi diharapkan dapat menjadi faktor diperolehnya genotip tanaman dengan masa pengisian biji yang lebih lama sehingga komponen hasil biji dapat meningkat. Hal ini selaras dengan kajian Nur et al. (2012) dan Natawijaya et al. (2012) yang menunjukkan bahwa karakter umur panen memiliki nilai heritabilitas yang tinggi. Dengan demikian, karakter ini dapat dipertimbangkan sebagai karakter seleksi pada generasi selanjutnya.

\section{KESIMPULAN}

Tanaman jagung generasi $F_{2}$ memiliki nilai variabilitas fenotipik dan genotipik relatif agak sempit kecuali pada karakter bobot tongkol dengan kelobot dan bobot tongkol tanpa kelobot yang memiliki variabilitas fenotipik agak luas. Nilai heritabilitas tinggi terdapat pada karakter seperti umur panen, umur berbunga jantan, dan umur berbunga betina. Nilai kemajuan genetik harapan yang tinggi diperoleh pada karakter seperti tinggi tanaman, jumlah baris biji, bobot 100-biji, dan bobot tongkol dengan kelobot.

\section{UCAPAN TERIMA KASIH}

Terima kasih disampikan kepada Universitas Bangka Belitung atas fasilitas lahan penelitian di kebun percobaan dan penelitian.

\section{DAFTAR PUSTAKA}

Ahmad SQ, Khan S, Ghaffar M, Ahmad F. 2011. Genetic diversity analysis for yield and other parameters in maize (Zea mays L.) genotypes. Asian Journal of Agricultural Sciences. 3(5): 385-388.

Aminasih, Nita. 2010. Penentuan Kriteria Seleksi 45 Galus Terigu (Triticum aestivum L.) Introduksi di Dempo Selatan, Pagar Alam, Sumatera Selatan. J. Penelitian Sains. 12:1(1-6).

Amzeri A. 2015. Dasar-dasar Pemuliaan Tanaman. Madura (ID): UTM-Press Bangkalan.

Amzeri A. 2019. Seleksi satu tongkol satu baris (ear to row selection) pada tanaman jagung (Zea mays L.). 
Rekayasa. 12(1): 18-23. https://doi.org/10.21107/ rekayasa.v12i1.5228

Apriliyanti N, Soetopo L. 2016. Keragaman genetik pada generasi $\mathrm{F}_{3}$ cabai (Capsicum annuum LI.). Jurnal Produksi Tanaman. 4(3): 209-217.

Barmawi M, Sa'diyah N, Yantama Y. 2013. Kemajuan genetik dan heritabilitas karakter agronomi kedelai (Glycine max [L.] Merrill) generasi $\mathrm{F}_{2}$ persilangan wilis dan Mlg2521. Prosiding Semirata FMIPA Universitas Lampung. Lampung (ID).

Bello OB, Abdulmaliq SY, Afolabi MS, Ige SA. 2010. Correlation and Path coefficient analysis of yield and agronomic characters among open pollinated maize varieties and their F1 hybrids in a diallel cross. African Journal of Biotechnology. 9(18): 2633-2639.

Bello OB. 2012. Heritability and genetic advance for grain yield and its related attributes in maize (Zea mays L.). J. Instasci. Micro. Biotech. 2:1-14.

CPVO. 2010. Protocol for Distinctness, Uniformity and Stability Test Zea Mays L. Angers City, Community Plant Variety Office: France (FR).

Effendy, Respatijarti, Waluyo B. 2018. Genetic variability and heritability characters of yield component and yield of physalis (Physalis sp.). Jurnal Agro. 5(1): 30-38. https://doi.org/ $10.15575 / 1864$

Farnia, A. and Meysam, M. 2015. Study on Morphological Characteristics of Maize (Zea mays L.) Cultivars under Different Plant Densities. Indian Journal of Natural Sciences. 5(30): 4391-4397.

Handayani T, Hidayat I. 2012. Keragaman genetik dan heritabilitas beberapa karakter utama pada kedelai sayur dan implikasinya untuk seleksi perbaikan produksi. Jurnal Hortikultura. 22(4): 327-333. https://doi.org/10.21082/jhort.v22n4.2012.p327333

[IBPGR] International Board for Plant Genetic Resourses. 1991. Descriptors for Maize. International Maize and Wheat Improvement Center: Mexico City, International Board for Plant Genetic Resourses: Rome.

Jameela H, Sugiharto AN, Soegianto A. 2014. Keragaman Genetik dan Heritabilitas Karakter Komponen Hasil pada Populasi F2 Buncis (Phaseolus vulgaris L.) Hasil Persilangan Varietas Introduksi dengan Varietas Lokal. Jurnal Produksi Tanaman. 2(4): 324-329.

Kristamtini, Sutarno, Wiranti EW, Widyayanti S. 2016. Kemajuan Genetik dan Heritabilitas Karakter Agronomi Padi Beras Hitam pada Populasi F2. Jurnal Penelitian Pertanian Tanaman Pangan. 15(2). 119-124. https://doi.org/10.21082/jpptp. v35n2.2016.p119-124
Khomaeni HS dan Suryadi B. 2015. Variabilitas dan Seleksi Awal Populasi Tanaman Teh Hasil Persilangan Buatan. Jurnal Penelitian Teh dan Kina. 14(2): 72-77.

Kusuma R, Sa'diyah N, Nurmiaty Y. 2016. Keragaman Fenotipe dan Heritabilitas Kedelai (Glycine max [L.] Merrill) Generasi $F_{6}$ Hasil Persilangan Wilis $x$ Mlg 252. Jurnal Penelitian Pertanian Terapan. 16(2): 85-93. https://doi.org/10.25181/jppt.v16i2.88

Leisolo MK, Riry J, Matatula E. 2013. Pengujian Viabilitas dan Vigor Benih Beberapa Jenis Tanaman yang Beredar di Pasaran Kota Ambon. Jurnal Agrologia. 2(1): 1-9. https://doi.org/ 10.30598/a.v2i1.272

[Litbang] Balai Penelitian dan Pengembangan Pertanian. 2016. Teknologi Budidaya Jagung. Lokal Pengkajian Teknologi Pertanian Sulawesi Barat. Sulawesi Barat.

Lubis K, Sutjahjo SH, Syukur M, Trikoesoemaningtyas. 2014. Pendugaan Parameter Genetik dan Seleksi Karakter Morfofisiologi Galur Jagung Introduksi di Lingkungan Tanah Masam. Penelitian Pertanian Tanaman Pangan. 33(2): 122-128. https://doi.org/ 10.21082/jpptp.v33n2.2014.p122-128

Lubis K, Sutjahjo SH, Syukur M, Trikoesoemaningtyas. 2015. Penampilan Beberapa Karakter Morfofisiologi Galur Introduksi Jagung (Zea mays L.). Jurnal Pertanian Tropik. 2(3): 246-250. https://doi.org/ 10.32734/jpt.v2i3.2927

Mangoendidjojo W. 2003. Dasar-dasar Pemuliaan Tanaman. Kanisius. Yoyakarta (ID). pp.182.

Maryenti T, Bermawi M, Prasetyo J. 2014. Heritabilitas dan Kemampuan Genetik Karakter Ketahan Kedelai Generasi F2 Persilangan Tanggamus x B3570 Terhadap Soybean Mosaic Virus. Jurnal Kelitbangan. 2(2): 137-153.

Mendez-Natera JR, Rondon A, Hernandes J, Merazo Pinto JF. 2012. Genetic studies in upland cotton. III. Genetic parameters, correlation and path analysis. SABRAO. Journal of Breeding and Genetics. 44(1): 112-128.

Moedjiono dan M. J. Mejaya. 1994. Variabilitas genetik beberapa karakter plasma nutfah jagung koleksi Balittas Malang. Zuriat. 5(2): 27-32.

Natawijaya A. 2012. Seleksi generasi awal segregan $F_{2}$ gandum (Triticum aestivum L.) untuk perbaikan daya hasil. Tesis. Sekolah Pascasarjana. Institut Pertanian Bogor. Bogor (ID).

Nur A, Trikoesoemaningtyas N, Khumaida S, Yahya 2012. Evaluasi dan keragaman genetik 12 galur gandum introduksi di lingkungan tropika basah. Jurnal Agrivigor. 11: 230-243.

Nzuve F, Githiri S, Mukunya DM, Gethi JF. 2014. Genetic variability and correlation studies of grain 
yield and related agronomic traits in maize. Journal of Agricultural Science 6(9): 166-176. https:// doi.org/10.5539/jas.v6n9p166

Ramadhani R, Damanhuri, Purnamaningsih. 2013. Penampilan Sepuluh Genotipe Cabai Merah (Capsicum annum L.). Jurnal Produksi Tanaman. 1(2): 33-41.

Sa'diyah N, Ardiansyah S, Barmawi M. 2013. Pola Segregasi Karakter Agronomi Tanaman Kedelai (Glycine max [L.] Merrill) Generasi F2 Hasil Persilangan Wilis X Malang 2521. Lampung (ID): Fakultas Pertanian Universitas Lampung.

Sadras VO, Slafer GA. 2012. Environmental modulation of yield components in cereals: Heritabilities reveal a hierarchy of phenotypic plasticities. Field Crop Research. 127: 215-224. https://doi.org/10.1016/j.fcr.2011.11.014

Suharsono, Yusuf M, Paserang AP. 2006. Analisis ragam, heritabilitas dan pendugaan kemajuan seleksi populasi F2 dari persilangan kedelai kultivar Slamet x Nokonsawon. Jurnal Tanaman Tropika. 9(2): 86-93.

Suhendrata T. 2012. Introduksi Beberapa Jagung Komposit Varietas Unggul pada Lahan Kering Dalam Upaya Menunjang Kedaulatan Pangan di Kabupaten Sragen. Balai Pengkajian Teknologi Pertanian Jawa Tengah. Semarang (ID).

Tatipata A, Yudono P, Purwantoro A, Mangoendidjojo W. 2004. Kajian aspek fisiologi dan biokimia deteriorasi benih kedelai dalam penyimpanan. IImu Pertanian. 11(2): 76-87.

Syukur M, Sujiprihati S, dan Yunianti R. 2012. Teknik Pemuliaan Tanaman. Depok (ID): Penebar Swadaya.

Wirawan, D., Rosmayati LAP. Putri. 2013. Uji potensi produksi beberapa galur/varietas gandum (Triticum aestivum L.) di dataran tinggi Karo. Jurnal Online Agroekoteknologi. 2: 1-15. 